\title{
Genetic toxicity in dab Limanda limanda from the North Sea
}

\author{
J. K. Chipman ${ }^{1}$, J. W. Marsh ${ }^{1}$, D. R. Livingstone ${ }^{2}$, B. Evans ${ }^{2}$ \\ ${ }^{1}$ School of Biochemistry, University of Birmingham, Edgbaston, Birmingham B15 2TT, United Kingdom \\ ${ }^{2}$ Plymouth Marine Laboratory, Citadel Hill, Plymouth, Devon PL1 2PB, United Kingdom
}

\begin{abstract}
During the Bremerhaven Workshop, a battery of assays was employed aimed at the detection of genetic damage in dab Limanda limanda and at an understanding of the influence of pollution on the metabolism of chemical pro-mutagens. The presence of chemical/DNA adducts was investigated by ${ }^{32} \mathrm{P}$-postlabelling (for bulky hydrophobic adducts) and by HPLC with electrochemical detection (for oxidised deoxyguanosine). No significant differences were seen between the various sites analysed along the transect. Bacterial mutagenicity assays (Salmonella typhimurium strains TA100 and TA98) were also unable to detect frame-shift or base-pair mutagens in liver extracts or in bile samples following treatment with the deconjugating enzyme, $\beta$-glucuronidase. There was no evidence of pollution-related unscheduled DNA synthesis in dab hepatocytes on the day after sampling. Unscheduled DNA synthesis was, however, induced by nitroquinoline oxide (but not 2-acetylaminofluorene) in dab hepatocytes from 2 stations of different pollution status. The extent of excision repair was similar at the 2 stations. Regarding the metabolism of pro-mutagens, liver enzymes were capable of converting 2 -acetylaminofluorene to bacterial mutagens; a process requiring $\mathrm{N}$-hydroxylation and deacetylation. The activation ability was greater in fish from the polluted stations $(3 \& 5)$ relative to Stns $6 \& 7$, and this may reflect the findings of others on cytochrome P450 induction.
\end{abstract}

\section{INTRODUCTION}

The Bremerhaven Workshop provided an opportunity to study the possible correlation between marine chemical contamination and biological responses. One aim of the sea-going workshop was to identify sensitive and quantitative assays of molecular changes that might be employed as 'early-warning' monitors of fish toxicity. We employed a battery of assays aimed at the detection of genetic damage and at an understanding of the influence of pollution on the handling of chemical pro-mutagens.

\section{METHODS}

Sampling of dab. Dab Limanda limanda were collected by net from various stations along the transect between $54^{\circ} 00^{\prime} \mathrm{N} / 08^{\circ} 00^{\prime} \mathrm{E}$ and $54^{\circ} 50^{\prime} \mathrm{N} / 05^{\circ} 35^{\prime} \mathrm{E}$ in the German Bight [precise details of Stns 1 (nearest to the coast) through to 9 (furthest from coast) are given elsewhere: Stebbing \& Dethlefsen 1992]. The transect traverses a known contamination gradient (Stebbing \& Dethlefsen 1992) and chemical support analyses are available for all stations sampled during the workshop (Cofino et al. 1992). In accordance with the common practise for related studies in the workshop programme, all fish were allowed a 6 h recovery period following docking before liver samples were taken during which time some repair of DNA adducts is possible. All dab used were randomly sampled, non overtly diseased females. The size range was 13 to $18 \mathrm{~cm}$ length except for those used for isolated hepatocyte studies (17 to $25 \mathrm{~cm}$ length).

Measurement of DNA adducts. Livers were excised and frozen to $-80^{\circ} \mathrm{C}$. The ${ }^{32} \mathrm{P}$-postlabelling assay was carried out essentially according to Gupta (1985).

DNA $(4 \mu \mathrm{g})$ was enzymatically hydrolyzed to deoxynucleoside 3 '-monophosphates and adducts were enriched by removing normal nucleotides using the butan-1-ol extraction procedure.

The adduct residue from $1 \mu \mathrm{g}$ of DNA was dissolved 
in $10 \mu \mathrm{l} \mathrm{H}_{2} \mathrm{O}$, and the ${ }^{32} \mathrm{P}$ labelling was initiated by addition of $5 \mu \mathrm{l}$ buffer mix (100 mM bicine, $100 \mathrm{mM}$ magnesium chloride, $100 \mathrm{mM}$ dithiothreitol and $10 \mathrm{mM}$ spermidine $\mathrm{pH} 9.6$ ) containing $100 \mu \mathrm{Ci}$ of ${ }^{32} \mathrm{P}$ ]ATP and 4 units of T4 polynucleotide kinase. After incubation at $37^{\circ} \mathrm{C}$ for $30 \mathrm{~min}, 40$ milliunits of apyrase was added and incubated for a further $30 \mathrm{~min}$.

Polyethyleneimine cellulose thin layer chromatography (TLC) of the ${ }^{32} \mathrm{P}$-labelled adducts was carried out with the omission of stage D2. D1 contained $1 \mathrm{M} \mathrm{Na}$ phosphate $\mathrm{pH} 6$. D3 contained $3 \mathrm{M}$ lithium formate 8.5 M urea $\mathrm{pH}$ 3.5. D4 contained $0.8 \mathrm{M}$ lithium chloride, $0.5 \mathrm{M}$ Tris $\mathrm{HCl} 8.5 \mathrm{M}$ urea $\mathrm{pH} 8.5$ and D5 contained $0.35 \mathrm{M} \mathrm{MgCl}_{2}$. Adducts were located by screen enhanced autoradiography using Kodak XAR-5 film. The detection limit of this assay is approximately 1 adduct in $10^{8}$ bases.

For the analysis of 8-hydroxydeoxyguanosine (8-oxodG), DNA was isolated by phenol extraction and enzymatically digested to the deoxynucleoside level with deoxyribonuclease 1, N Crassa endonuclease, phosphodiesterase I (Crotalus atrox) and E. coli alkaline phosphatase. The 8-hydroxydeoxyguanosine standard was synthesised by the Udenfriend system and its structure was confirmed by mass spectroscopy (Winyard et al. 1990). Digested DNA samples were analysed for 8 -oxodG by reverse phase high performance liquid chromatography (HPLC) with electrochemical detection. Deoxyguanosine was detected by UV absorption (Winyard et al. 1990).

Mutagenicity assays. Livers and gall bladders were excised and frozen to $-80^{\circ} \mathrm{C}$. Liver and bile samples were then tested for the presence of pro-mutagens. Bile was pooled from 4 to 6 gall bladders from each station and sterilized by filtration $(0.2 \mu \mathrm{m})$. Samples $(100 \mu \mathrm{l})$ were then tested for mutagenicity towards Salmonella typhimurium strains TA98 and TA100 in a pre-incubation assay (Maron \& Ames 1983) in the presence of $\beta$-glucuronidase H-2S, Sigma; 1000 units and $10 \%$ Aroclor-induced rat liver $9000 \times g$ supernatant (S9) (Maron \& Ames 1983). Incubations with bacteria were for $20 \mathrm{~min}$ at $25^{\circ} \mathrm{C}$ prior to plating. For negative and positive controls, bile from control rats or rats pre-treated $15 \mathrm{mg} \mathrm{kg}^{-1}$ by intraperitoneal injection) with 2-amino-3,4dimethylimidazo (4,5-f) quinoline (MelQ) (Percy \& Chipman 1989) were used respectively.

Dab liver $\mathrm{S} 9$ were tested for the pres- ence of promutagens in the same way with strain TA98 but without the addition of $B$-glucuronidase or rat liver S9.

The activity of dab liver enzymes involved in the metabolic activation of a model pro-mutagen 2-acetylaminofluorene (2AAF) was also studied. Dab liver S9 $(10 \%)$ was used in a pre-incubation mutagenicity assay with Salmonella typhimurium strain TA98 (Maron \& Ames 1983) as above. 2AAF was added at 200 nmol plate ${ }^{-1}$.

Measurement of unscheduled DNA synthesis. Unscheduled DNA synthesis was measured in cultured dab hepatocytes with and without the addition of the genotoxic agents 4 -nitroquinoline 1 -oxide (NQO) and 2AAF.

Approximately half of each liver was sliced into small pieces $(<2 \mathrm{~mm}$ cubes), placed in a Trypsinising flask (Belco) containing $50 \mathrm{ml}$ of Earles $\mathrm{Ca}^{2+} / \mathrm{Mg}^{2+}$ free balanced salt solution (ICN Flow) to which had been added $5 \mathrm{mM}$ EDTA and $0.5 \% \mathrm{NaCl}$ and incubated for $30 \mathrm{~min}$ with continuous agitation. The divalent cations $\mathrm{Ca}^{2+}$ and $\mathrm{Mg}^{2+}$ are thought to be involved in intercellu-

\section{a}

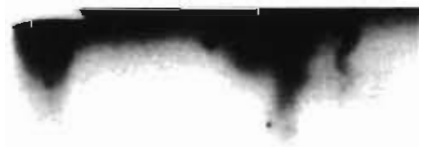

\section{b}
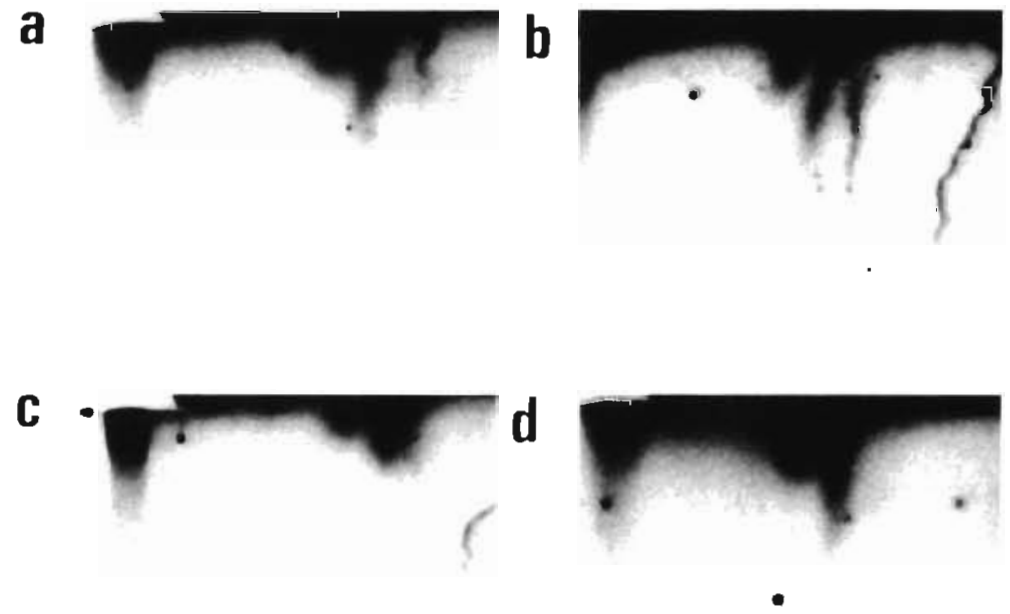

$\mathbf{e}$
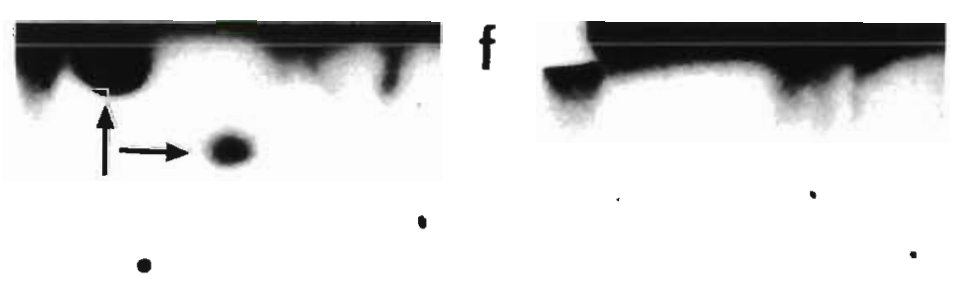

Fig. 1 Autoradiographs of chromatograms following ${ }^{32} \mathrm{p}$-postlabelling of: (a to d) dab hepatic DNA digests sampled from Stns 3,5,6 \& 7 respectively; (e) positive control, rat injected i.p. with $50 \mathrm{mg} \mathrm{kg}^{-1} 2 \mathrm{AAF}$ and (f) negative control, lacking DNA 
lar attachment; their absence from the incubation medium and the presence of the chelating agent EDTA results in competition for these ions and their ultimate removal from the intercellular plaque thereby facilitating the disaggregation procedure. The primary incubation also served to remove the majority of blood cells that would otherwise contaminate the hepatocyte preparation. The whole process of disaggregation, including centrifugation, was carried out at $10^{\circ} \mathrm{C}$ and all solutions used were sterile. The contents of the flask were then poured over $280 \mu \mathrm{m}$ plankton netting, the filtrate discarded and the retained solid material placed back into the flask plus $30 \mathrm{ml}$ of Hanks balanced salt solution (ICN Flow) to which had been added $25 \mathrm{mg} \mathrm{NaCl}, 42.5 \mathrm{mg} \mathrm{NaHCO}, 23.5 \mathrm{mg}$ HEPES, $0.02 \mathrm{ml} 1 \mathrm{M} \mathrm{HCl}, 5 \mathrm{mg}$ of collagenase (Sigma Type IV) and $5 \mathrm{mg}$ of lipase. The tissues were incubated in the enzyme solution for $40 \mathrm{~min}$, with continuous agitation, and the resulting cell suspension poured through $280 \mu \mathrm{m}$ plankton netting into $25 \mathrm{ml}$ centrifuge tubes and the cells spun down at $1000 \mathrm{rpm}(200 \times \mathrm{g})$ for $2 \mathrm{~min}$. To wash the cells the supernatant was decanted off and the cells resuspended in the same balanced salt solution, but without the addition of the digestive enzymes, and centrifuged as before. This washing procedure was repeated 3 times. Following the final wash the cells were resuspended in $25 \mathrm{ml}$ of an amended Eagles Minimum Essential Medium (ICN Flow) (containing additionally $25 \mathrm{ml}$ foetal bovine serum, $5 \mathrm{ml}$ of non-essential amino acids and $5 \mathrm{ml}$ of $200 \mathrm{mM} \mathrm{L}$-glutamine $1^{-1}$ ) and stored at $10^{\circ} \mathrm{C}$.

The DNA repair assay was based on that of Williams et al. (1982) with various modifications. Hepatocytes (approximately $5 \times 10^{5}$ ) were plated onto $25 \mathrm{~mm}$ round Thermanox coverslips (Lux Scientific from Flow Laboratories) in $35 \mathrm{~mm}$, 6-well dishes (Cel-Cult, Sterilin Ltd, UK) at $10^{\circ} \mathrm{C}$. The culture medium (2 ml) was Leibovitz-15 (Sigma) containing $2.5 \%$ foetal calf serum. Viability of hepatocyte preparations varied considerably between 50 to $92 \%$ as assessed by trypan blue exclusion and the extent of cell attachment to culture vessels (which acted in selecting viable cells) was also variable. In cases where cell attachment was less than $1 \times 10^{5}$, cultures were not used. Four hours after plating, the medium was replaced with $2 \mathrm{ml}$ serum-free Leibovitz-15 containing streptomycin $(200 \mu \mathrm{g})$, the test compound in dimethylsulphoxide $(20 \mu \mathrm{l})$ and $\left[{ }^{3} \mathrm{H}\right]$-thymidine $(10 \mu \mathrm{Ci}$;
$87 \mathrm{Ci} \mathrm{mmol}{ }^{-1}$ ). The plates were then incubated for a further $20 \mathrm{~h}$ at room temperature. The cells were fixed and processed for autoradiographic analysis of nuclear uptake of $\left[{ }^{3} \mathrm{H}\right]$-thymidine as described elsewhere (Chipman \& Davies 1988). Exposure to emulsion was for $30 \mathrm{~d}$ at $4{ }^{\circ} \mathrm{C}$ (Walton et al. 1984).

\section{RESULTS}

\section{Analysis of DNA adducts}

The results of the the TLC analysis of ${ }^{32} \mathrm{P}$-postlabelled bulky hydrophobic adducts in dab liver are shown in Fig. 1. The positive control liver from a male Wistar rat (pre-treated with $50 \mathrm{mg} \mathrm{kg}^{-1} 2 \mathrm{AAF}$ i.p. $16 \mathrm{~h}$ before sampling) shows the presence of 2 major radiolabelled adducts. Under identical conditions of analysis, there was no evidence for adducts in the dab liver samples from Stns 3, 5, 6 \& 7. Faint, nondiscrete areas of radiolabel were seen on TLC plates from all samples but there was no difference between the stations and these were also seen in the control and treated rat samples. It can be concluded that the chemical pollution gradient was not related to detectable levels of bulky hydrophobic adducts. A repeat-analysis gave similar results.

Evidence of oxidative DNA damage was investigated by analysis of hydroxyl-radical adducted to deoxyguanosine. Table 1 shows the level of 8-oxodG in dab liver from various stations. The oxidised deoxynucleoside was found in all liver samples but there was no significant elevation at any particular station. Oxidative DNA damage could, therefore, not be correlated to the extent of chemical pollution.

Table 1. Limanda limanda. Detection of 8-hydroxydeoxyguanosine (8-oxodG) in dab liver. The level of 8-oxodG is expressed relative to the level of $\mathrm{dG}$ which was measured by electrochemical activity and UV absorbance respectively following separation by HPLC

\begin{tabular}{|lccc|}
\hline Station \& sample & dG (nmol) & 8-oxodG (pmol) & \% Adduct \\
\hline $3 \mathrm{i}$ & 1.695 & 0.315 & 0.018 \\
$3 \mathrm{ii}$ & 1.046 & 0.314 & 0.030 \\
$3 \mathrm{iii}$ & 1.853 & 0.786 & 0.042 \\
$5 \mathrm{i}$ & 2.558 & 1.340 & 0.052 \\
$5 \mathrm{ii}$ & 2.083 & 0.524 & 0.025 \\
$5 \mathrm{iii}$ & 3.720 & 0.871 & 0.023 \\
$6 \mathrm{i}$ & 1.163 & 0.559 & 0.048 \\
$6 \mathrm{ii}$ & 1.889 & 0.373 & 0.020 \\
$6 \mathrm{iii}$ & 1.204 & 0.583 & 0.048 \\
$7 \mathrm{i}$ & 2.084 & 0.652 & 0.031 \\
$7 \mathrm{ii}$ & 1.223 & 0.280 & 0.023 \\
$7 \mathrm{iii}$ & 2.269 & 0.559 & 0.025 \\
\hline
\end{tabular}


Table 2. Limanda limanda. Assay of dab bile for bacterial mutagens. Bile samples $(100 \mu 1)$ were tested for mutagenicity in the presence of $\beta$-glucuronidase and Aroclor-induced rat liver 59 . The spontaneous reversion rate (not subtracted from values given) was $200 \pm 21$ and $35 \pm 4$ for strains TA100 and TA98 respectively

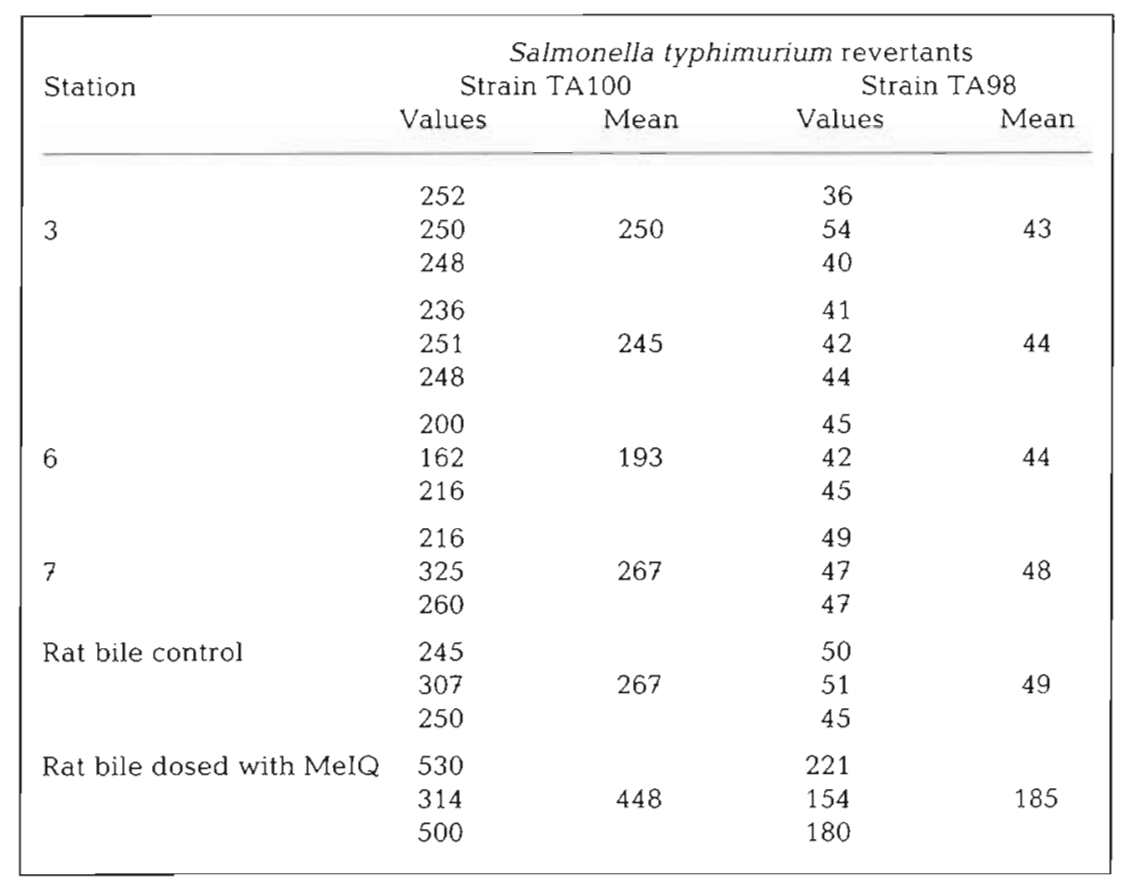

gave approximately a 5-fold increase above the spontaneous reversion rate with strain TA98. However all dab bile samples gave a negative response (in compliance with common practise a 2 -fold increase in mutagenicity is taken as the criterion for a positive result). Although dab liver S9 samples were also non-mutagenic to Salmonella (Table 3), all dab liver S9 samples were capable of converting the pro-mutagen 2AAF to a mutagenic species (Table 3). The S9 prepared from the livers of dab from Stns 3 \& 5 (close to the shore) activated $2 \mathrm{AAF}$ to a significantly greater extent $(p<0.01)$ than those for Stns $6 \& 7$. There was no significant difference in the activating ability of liver $\mathrm{S} 9$ between fish from Stns $3 \& 5$, or between fish from Stns 6 \& 7 (ANOVA was used for statistical analysis).

\section{Mutagenicity studies}

The bacterial mutagenicity of bile samples from dab is shown in Table 2. The positive control (bile from a rat treated with the pro-mutagen MeIQ)

Table 3. Limanda Iimanda. Bacterial mutagenicity assays with dab liver $9000 \times g$ supernatant (S9). Values are the number of histidine-revertant colonies following pre-incubation at $25^{\circ} \mathrm{C}$ for 20 min with Salmonella typhimurium strain TA98. The spontaneous reversion rate (not subtracted) was $28 \pm 4$ (with 2AAF but without S9). 2AAF was administered at a dose of 200 nmol plate ${ }^{-1}$

\begin{tabular}{|c|c|c|}
\hline \multirow[t]{2}{*}{ Station } & \multicolumn{2}{|c|}{ Number of revertant colonies } \\
\hline & Dab $\$ 9$ alone & Dab $\mathrm{S} 9+2 \mathrm{AAF}$ \\
\hline \multirow{3}{*}{3} & 24 & 190 \\
\hline & 18 & 122 \\
\hline & 20 & 146 \\
\hline \multirow{3}{*}{5} & 15 & 131 \\
\hline & 20 & 120 \\
\hline & 12 & 120 \\
\hline \multirow{3}{*}{6} & 30 & 72 \\
\hline & 21 & 53 \\
\hline & 19 & 60 \\
\hline \multirow{3}{*}{7} & 19 & 82 \\
\hline & 20 & 91 \\
\hline & 22 & 76 \\
\hline
\end{tabular}

\section{Unscheduled DNA synthesis}

The extent of $\left[{ }^{3} \mathrm{H}\right]$-thymidine incorporation (indicative of DNA repair) in hepatocytes untreated or treated with $2 \mathrm{AAF}$ or NQO is shown in Table 4 . There is no evidence of DNA repair activity in untreated cells taken from any of the stations analysed. Unscheduled DNA synthesis was also not observed in cells treated with $50 \mu \mathrm{M} 2 \mathrm{AAF}$ (a dose level that causes extensive repair synthesis in rat hepatocytes; Chipman \& Davies 1988). NQO, however, at a concentration of $10 \mu \mathrm{M}$ caused an increase in the net nuclear grain count compared to controls. Other groups have taken a net nuclear grain count of $>5$ or $>3$ to be indicative of a positive effect (Williams et al. 1982, Walton et al. 1984). This positive effect was seen in dab hepatocytes from both Stns $3 \& 6$ and there was no significant difference between samples from the 2 stations.

\section{DISCUSSION}

The assays employed to detect genetic damage (bulky hydrophobic adducts, DNA oxidation and unscheduled DNA synthesis on the day after sampling) revealed no evidence for genetic toxicity in dab liver related to chemical pollutant exposure. Although adduct analysis may have some potential in pollution 
Table 4. Unscheduled DNA synthesis in dab hepatocytes. Hepatocytes were incubated for $20 \mathrm{~h}$ at room temperature with $10 \mu \mathrm{Cil}{ }^{3} \mathrm{H}$-thymidine and processed for autoradiography. Values are the mean net nuclear grain counts for control hepatocytes or hepatocytes treated with $2 \mathrm{AAF}(50 \mu \mathrm{M})$ or $\mathrm{NQO}(10 \mu \mathrm{M})$

\begin{tabular}{|lcccc|}
\hline \multirow{2}{*}{ Station } & Sample code & \multicolumn{3}{c|}{ Net nuclear grain count } \\
& & No treatment & 2AAF & NQO \\
\hline \multirow{4}{*}{6} & 429 & -2.1 & -1.6 & 7.2 \\
& 421 & -3.5 & -2.0 & 4.3 \\
& 427 & -0.1 & -0.3 & 5.8 \\
5 & 420 & -2.1 & 0.1 & \\
& 418 & -3.2 & -0.1 & Not available \\
& 414 & -1.0 & -0.6 & \\
3 & 437 & -0.2 & -0.5 & 3.4 \\
& 438 & -2.1 & -2.1 & 5.9 \\
& 439 & -0.6 & -1.6 & 4.1 \\
\hline
\end{tabular}

chrome P450 (1A family) correlates with the extent of chemical pollution. Thus although no evidence could be provided for genetic damage down to the limits of sensitivity of the various assays employed, the potential for the chemically-polluted fish to be more susceptible to pro-mutagenic substances has been demonstrated. A similar finding was reported for the effect of pollution on fish from the Spanish South-Atlantic littoral (RodriguezArija et al. 1991). The ability to carry out excision repair of DNA damage (albeit at a low level with NQO and not at all with 2 AAF) by dab from two of the stations was

monitoring (Dunn et al. 1987, Varanasi et al. 1989) the level of pollution necessary for detection by this endpoint may be extensive. This view is also expressed by Ray et al. (1992) and is reflected in the findings of Kurelec et al. (1989) who reported similarities in adduct profiles (when comparing polluted versus relatively clean sites) in the livers of whales and various fish respectively. There was no evidence of 'endogenous' adducts as reported by Kurelec for some (but not all) aquatic species (Kurelec et al. 1988, 1989). This difference may be due to minor differences in the assay protocol which will affect both sensitivity and the nature of the adducts detected. The occurrence of apparent endogenous adducts may also be seasonal (Kurelec et al. 1990). The consistency in the level of oxidised deoxyguanosine in the liver of fish from various sites is not reflected by the findings of Moore (1992) who demonstrated a relatively high rate of production of oxyradicals in dab hepatocytes from Stns $3 \& 5$. It may be that the elevated oxygen radicals do not have access to the DNA and in this respect the relatively high levels of antioxidant enzymes in the polluted sites (Livingstone et al. 1992) may provide adequate protection. Analyses of liver $9000 \times g$ supernatants and bile samples for pro-mutagens that may have resided in the tissue or were being excreted were also negative. Regarding the handling of pro-mutagens, liver enzymes were capable of converting $2 \mathrm{AAF}$ to bacterial mutagens. This process has been shown to be dependent on cytochrome P450-mediatated $\mathrm{N}$-hydroxylation and deacetylation (Thorgeirsson et al. 1984) although flavin monooxygenase can also hydroxylate the deacetylated 2-aminofluorene. The activation ability was greater in fish from the relatively polluted Stations ( $3 \& 5$ ) relative to Stns $6 \& 7$, and this may relate to the findings of others at the workshop (e.g. Renton \& Addison 1992) that the activity of cyto- also demonstrated. The repair activity was similar for the 2 sites of different pollution status and agrees with a positive effect reported in trout hepatocytes with NQO (Walton et al. 1984). The findings suggest that the DNA repair system is not impaired at the station with relatively high chemical contamination.

Finally it was also reported from this Workshop (see Köhler et al. 1992, Simpson \& Hutchinson 1992) that the incidence of foci of cellular alteration was greater in livers from inshore sites. In the light of the lack of extensive genetic toxicity, epigenetic mechanisms of formation of these putative preneoplastic changes should also be considered.

\section{LITERATURE CITED}

Chipman, J. K., Davies, J. E. (1988). Reduction of 2-acetylaminofluorene-induced unscheduled DNA synthesis in human and rat hepatocytes by butylated hydroxytoluene. Mutation Res. 207: 193-198

Cofino, W. P., Smedes, F., de Jong, S. A., Abarnou, A., Boon. J. P., Oostingh, I., Davies, I. M., Klungsøyr, J., Wilhelmsen, S., Law, R. I., Whinnett, J. A., Schmidt, D., Wilson, S. (1992). The chemistry programme. Mar. Ecol. Prog. Ser. 91: $47-56$

Dunn, B. P., Black, J. J., Maccubbin, A. (1987). ${ }^{32}$ P-postlabeling analysis of aromatic DNA adducts in fish from polluted areas. Cancer Res. 47: 6543-6548

Gupta, R. C. (1985). Enhanced sensitivity of ${ }^{32} \mathrm{P}$-postlabeling analysis of aromatic carcinogen: DNA adducts. Cancer Res. 45: 5656-5662

Köhler, A., Deisemann, H., Lauritzen, B. (1992). Histological and cytochemical indices of toxic injury in the liver of dab Limanda limanda. Mar. Ecol. Prog. Ser. 91: 141-153

Kurelec, B., Chacko, M., Gupta, R. C. (1988). Postlabeling analysis of carcinogen-DNA adducts in mussel, Mytilus galloprovincialis. Mar, environ. Res. 24: 317-320

Kurelec, B., Garg, A., Krca, S., Chacko, M., Gupta, R. C. (1989). Natural environment surpasses polluted environment in inducing DNA damage in fish. Carcinogenesis 10 : $1337-1339$ 
Kurelec, B., Garg, A., Krca, S., Gupta, R. C. (1990). DNA adducts in marine mussel Mytilus galloprovincialis living in polluted and unpolluted environments. In: McCarthy, J. F., Stugart, L. R. (eds.) Biomarkers of environmental contamination. Lewis publishers, Chelsea, p. 217-227

Livingstone, D. R., Archibald, S., Chipman, J. K., Marsh, J. W. (1992). Antioxidant enzymes in liver of dab Limanda limanda from the North Sea. Mar. Ecol. Prog. Ser. 91: $97-104$

Maron, D. M., Ames, B. N. (1983). Revised methods for the Salmonella mutagenicity test. Mutation Res. 113: 173-215

Moore, M. N. (1992). Molecular cell pathology of pollutant-induced liver injury in flatfish: use of fluorescent probes. Mar. Ecol. Prog. Ser. 91: 127-133

Percy, A. J., Chipman, J. K. (1989). Biliary excretion of the pro-mutagen 2-amino-3,4-dimethylimidazo $(4,5$-f) quinoline (MelQ) and intestinal nuclear toxicity in the rat. Proceedings of the $\mathrm{V}$. Int. Cong. Toxicol., Brighton, UK

Ray, S., Dunn, B. P., Payne, J. F., Fancey, L., Helbig, R., Beland, P. (1992). Aromatic DNA-carcinogen adducts in Beluga whales (Delphinapterus leucas) from the Canadian arctic and the gulf of St Lawrence. Mar. Pollut. Bull. (in press)

Renton, K. W., Addison, R. F. (1992). Hepatic mono-oxygenase activity and P450lA mRNA in North Sea dab Limanda limanda from contaminated sites. Mar Ecol. Prog. Ser. 91: 65-69

Rodriguez-Ariza, A., Dorado, G., Peinado, C., Pueyo, C.,
Lopez-Barea, $J$ (1991). Biochemical effects of environmental pollution in fishes from the Spanish South-Atlantic littoral. Biochem. Soc. Trans. 19: 301S

Simpson, M. G., Hutchinson, T H. (1992). Toxicological pathology of dab Limanda limanda along pollution gradients in the southern North Sea. Mar. Ecol. Prog. Ser 91 $155-161$

Stebbing, A. R. D., Dethlefsen, V. (1992). Introduction to the Bremerhaven Workshop on Biological Effects of Contamination. Mar. Ecol. Prog. Ser. 91: 1-8

Thorgeirsson, S. S., McManus, M. E., Glowinski, I. B. (1984). Metabolic processing of aromatic amides. In: Mitchell, J. R., Horning, M. G. (eds.) Drug metabolism and drug toxicity. Raven Press, New York, p. 183-197

Varanasi, U., Reichert, W. L., Stein, J. E. (1989). 32P-postlabeling analysis of DNA adducts in liver of wild English Sole (Parophrys vetulus) and Winter Flounder (Pseudopleuronectes americanus). Cancer Res. 49: 1171-1177

Walton, D. G., Acton, A. B., Stich, H. F. (1984). DNA repair synthesis following exposure to chemical mutagens in primary liver, stomach and intestinal cells isolated from rainbow trout. Cancer Res. 44: 1120-1121

Williams, G. M., Laspia, M. F., Dunkel, V. C. (1982). Reliability of the hepatocyte primary culture/DNA repair test in testing of coded carcinogens and non carcinogens. Mutation Res. 97: 359-370

Winyard, P. G., Perrett, D., Blake, D. R., Harris, G., Chipman, J K. (1990). DNA oxidation products. Analyt. Proc. 27: $224-227$ 